\title{
Saviors, naïfs, or orphans? \\ The posthuman condition in literary and cinematic perspectives on human cloning
}

\section{IVAN LACKO}

DOI: https://doi.org/10.31577/WLS.2021.13.1.4

Post- and transhuman narratives in literary fiction and cinema often make use of a whole assortment of themes (e.g., human enhancement, cyborgization, rapid technological development, cyberspatial consciousness, humanoid artificial intelligence, and biohacking), thus allowing the application of a broad variety of storylines, plots, and characters. A number of literary and cinematic works feature genetic engineering, DNA manipulation, and human cloning as intriguing and often controversial issues that enable powerful psychological, social, and political insights into posthuman societies. The aim of this article is to focus on three works of (science) fiction written between the 1970s and the 2010s to provide an analytical look at how characters who are human clones are used to discuss and address posthumanist and transhumanist issues.

While the theoretical background for the analysis will make use mostly of posthumanist criticism and theory, philosophical posthumanism, and literary criticism, the analysis itself will deal with Kate Wilhelm's acclaimed science-fiction novel Where Late the Sweet Birds Sang (1976), Kazuo Ishiguro's successful dystopia Never Let Me Go (2005), and Space and BBC America's popular five-season television series Orphan Black (2013-2017). The objective is to present the fictional microcosms of these works as valid and relevant societies in which human cloning serves as a backdrop for creating characters who, in turn, serve as pertinent elements in a posthuman environment. The article seeks to use the three selected works as representatives of a development in the portrayal of clone characters - from an impersonal presentation of the clones' collective mentality and lack of imagination, to more fully developed psychological portraits.

\section{POSTHUMAN IDENTITIES}

Francesca Ferrando has argued that human identity "has [been] formed, historically and theoretically, through the construction of the 'Other' [...] marking the shifting borders of what would become 'the human' through a process of performative rejections" $(2014,217)$. As opposed to the physical body, whose otherness has stemmed from a monstrous or freakish appearance, identity in the posthuman

* This article was supported by the project APVV-17-0064 "Analysis of multidimensional forms of trans- and post-humanism". 
context is a much more fluid and problematic concept (especially when the characters include clones, bioengineered beings, or machines with a human appearance). This is important, because ultimately "how one feels about the posthuman depends to a great extent on how one relates to the human in the first place" (Braidotti 2013, 194), and, as Judith Halberstam and Ira Livingstone have posited, "[t]he posthuman does not necessitate the obsolescence of the human; it does not represent an evolution or devolution of the human [but] participates in redistributions of difference and identity" $(1995,10)$. In posthuman narratives, such as the ones that will be discussed below, it is therefore crucial to present how humans and posthumans (or even non-humans) interact with and relate to each other. In the words of Rosi Braidotti, in order to approach the posthuman condition critically, its subjects should "enter into new affective assemblages [and] co-create alternative ethical forces and political codes" $(2017,21)$.

In A Critical History of Posthumanism, Andy Miah claims that our analytical standpoint towards posthumanity should involve "interconnected discourses and philosophical claims surrounding concepts of mind, body, nature and artifice [while acknowledging] concepts that have emerged and the cultural, political and media instantiations through which moral claims about a shift of humanisms can be asserted" $(2008,91)$. This requires a more open and accepting attitude towards diverse expressions of posthumanity, including bodies and identities which are easily labelled as different. Along a similar vein of thought, Manuela Rossini contends that it is important to address the fear of "encountering posthuman bodies" and advance towards welcoming them "as paradigms of a future posthumanity in a world where difference can be celebrated rather than used for the objectification and suppression of 'the Other"' $(2005,27)$. In other words, we need what Braidotti refers to as a new "posthuman social agenda" $(2013,196-97)$, which would reflect the posthuman condition more relevantly and which could help "enlarge the frame and scope of subjectivity along the transversal lines of post-anthropocentric relations" (82).

The transversality of such relations is important because it can help expose the "androcentric and heteronormative bias of what count as intrinsic human qualities" (Rossini 2005, 26) and, in a posthuman condition, present a chance to review our understanding of humanity as an ever-growing symbiotic system of humans, non-humans, and new-humans. In addition to the importance of such a synergetic system, posthuman societies ought to seek to abolish any preoccupation with rule and control of what Katherine Hayles has described as the "emergent processes" in which posthuman bodies and environments arise; for Hayles, the "posthuman conscious agency" is the most important element in the process of the formation of such bodies and environments $(1999,288)$. In this respect, the narratives studied herein also address the relevance of whether the clones in the stories are aware of their origin as well as to what extent this (lack of) awareness may affect their identity.

As Bruce Clarke and Manuela Rossini successfully argue, posthuman literary plots and characters have long been part of literary endeavors and have covered a multitude of themes; what is more, "literature and fiction have always been privileged speculative discourses haunted by the ghosts of humans, non-humans, and posthu- 
mans" (2017, xv). Besides the wide-ranging consideration of art playing an equally important role in trans- and posthumanism as technology (Vita-More 2013, 18), literary devices have been successful at familiarizing readers with "the Other", from a whole range of narratives about imaginary doubles, or doppelgängers, or a frequent focus on simulacra and hyperreality, to effectively addressing not only unequivocally human but also non-human phenomena and issues (Karkulehto, Koistinen, and Varis 2019,10$)$. When focusing on human cloning, presently an illegal and presumably only fictional practice, literary and cinematic genres allow the human imagination to pass beyond the present moment "[making] experience possible and [generating] lines of time and futurity beyond present experience" (Collebrook 2017, 199). In other words, as Bakošová and Odorčák propose in relation to Samuel Scheffler's assumption about intrinsic human altruism, "only the existence of an ongoing future of the world and humans can render their current lives meaningful" (2020, 54-55).

\section{CLONES AND MONSTERS}

The cloning of a human would deem any outer expressions of "otherness" secondary, as the genetic similarity between the clone and its original accounts for the clones being copies rather than visibly different beings. As Simona Micali posits, in fiction, "the peculiar figure of the clone [can be] particularly suitable for highlighting the problematic component in the theme of the subhuman. As an identical copy of man, in both appearance and behavior its monstrosity is no way physical but metaphysical" $(2019,68)$. It is the mode of origination that establishes "the Other" (or defines the subhuman) and might consequently impose social or political roles on clones. Since "most of the ethical and bioethical dilemmas related to cloning or enhancing human beings are mostly absent when relating to other species" (Ferrando 2019, 136), the so-called "clone narratives" have become interesting sources of discussion about posthuman bodies and subjectivity. Manipulating the genetic code, a competence presumed to be only acceptable in nature (or among the gods), gives fictional scientists power and influence while reinforcing hierarchical social structures. When discussing Jürgen Habermas's and Francis Fukuyama's pessimistic views on posthumanist development and genetic enhancement, Sarah Franklin posits that such a suspicious attitude identifies "genetic manipulation as a force unto itself, hostile to social order and integration" $(2006,87)$. As a result, and this is clearly visible in the analyzed works, human clones (as well as designer children) have become "iconic signifier[s] of the dilemmas and risks posed by new genetic technologies" (86).

The dilemmas, understandably, have brought forward numerous objections to human cloning. For example, cloning human children is considered problematic not only "because it violates the right to autonomy: by choosing a child's genetic makeup in advance, parents deny the child's right to an open future," but also because specific genetic enhancements "would point children toward particular choices, and so designer children would never fully be free" (Sandel 2013, 72). In other words, children cloned from people with successful life paths would be expected to follow either the same or similar careers, thus pre-determining their identity, at least 
in part. Gregory E. Pence makes a similar argument, drawing a parallel with Immanuel Kant's ideas about "authentic personhood" which should be "chosen and not imposed"; in other words, "people [themselves] should make choices about who they are rather than having it imposed on them by external forces or other people" (2016, 180). When talking about clones in fictional stories, any considerations about identity require "acknowledging the dazzling complexity of interactions between brain, mind, sensation, expression and bodily gesture that go into the making (and perhaps the myth) of recognizable and autonomous personhood" (Goulet and Rushing 2018, 14). This complexity is at the heart of how the three clone narratives create a literary impact in their respective posthuman microcosms.

Ethical concerns, moral dilemmas, and drawing a line between what is considered to be medically relevant or therapeutic and what is already the unnecessary enhancement or power-driven transformation of individuals (or entire species) have been frequently discussed and disputed (Ferrando 2019, 137). Literature and cinema have been quite prolific in presenting fictional accounts of the subjectivity and identity of engineered beings (clones or others) as well as their objectification, commodification, and potential danger to society. As early as 1818, Mary Shelley's Frankenstein raised concerns about the advancement of science at the expense of a moral capacity for understanding the price of progress upon the background of a story of a man-made being. In 1896, H.G. Wells' The Island of Doctor Moreau presented such issues as moral responsibility and the significance of human identity using the example of characters created by vivisection. Both novels introduced the now archetypal character of the mad scientist who is unable to see the intricate cause-and-effect reality behind the Romantic desire to subjugate nature to human will.

In his scientific and progressive endeavor to create a living being, Victor Frankenstein claims that for him financial success was only secondary and that the principal aim of his effort was to "banish disease from the human frame and render man invulnerable to any but a violent death!" (Shelley 2012, 42). His is a noble end, it seems, despite the fact that the objective is far from modest - he yearns to create a whole new life form: "A new species would bless me as its creator and source; many happy and excellent natures would owe their being to me" (47). Frankenstein's failure is inevitable when his creature starts to express human desires and becomes all too human. The humanity of the "monster" elicits sympathy, not unlike the pity that Prendick feels for the Beast Folk in The Island of Doctor Moreau. However, Moreau's experiments are portrayed as utterly cruel and barbaric, and his character represents the idea that scientific enhancement stands above sentiment or morality. One of the most famous quotes from Wells's book proves this when Moreau says: "To this day I have never troubled about the ethics of the matter. The study of Nature makes a man at last as remorseless as Nature" $(2005,75)$.

The Romantic (Gothic) character of 19th-century stories featuring enhanced or bioengineered beings makes it difficult to discuss their identity in complex psychological or social terms. Moreau, for example, had to escape civilization to continue his horrific experiments on a remote island, and, at the end of the novel, Prendick looks at the civilized society in London, fearing the animal part of each individual, and 
is unable to get over it (Wells 2005, 130). Any attempt at accommodating otherness (or outright monstrosity) is, therefore, doomed to failure, or, in the words of Christopher Peterson: "All forms of belonging - no matter how open and hospitable they are toward others - inevitably produce 'beasts' (both human and non-human) whose exclusion functions at cross purposes with our apparent desire for inclusivity and nonviolence" $(2011,133)$. This is an important insight for further discussion about clones as fictional characters, particularly in the light of their being perceived as copies, or Baudrillardian simulacra, devoid of originality and profound meaning.

\section{COPIES AD INFINITUM?}

In his seminal book Simulacra and Simulation, Jean Baudrillard introduced the simulacrum as part of a chain-like order of representational meaning attached to objects. From initially mirroring a meaningful reality, simulacra pass through several stages of development and transformation until the copying process has no profound reality to represent and ends up as a mere simulation $(1994,6)$. In his book, Baudrillard also discusses clones, whom he refers to as "human cuttings ad infinitum", simulacra of sorts, comparable to the literary "double":

[T] he imaginary power and wealth of the double - the one in which the strangeness and at the same time the intimacy of the subject to itself are played out (heimlich/unheimlich) - rests on its immateriality, on the fact that it is and remains a phantasm. Everyone can dream, and must have dreamed his whole life, of a perfect duplication or multiplication of his being, but such copies only have the power of dreams, and are destroyed when one attempts to force the dream into the real (95).

Consequently, it can be expected that clones or bioengineered beings, when used as fictional characters, would seek to identify their parent, original, or maker as part of their quest for identity. This is an important component of the plot in Orphan Black, a marginal feature of Never Let Me Go, and a non-existent element in Where Late the Sweet Birds Sang. However, the strangeness brought about by the genetic similarity is present in all of the works, alluding to such well-known concepts as Sigmund Freud's "Unheimlich" or "uncanny" (1919) and Masahiro Mori's notion of "bukimi no tani", translated as "uncanny valley" (2012). The uneasiness caused by the knowledge that a person's genome could be used to create a copy of themselves can have deep psychological implications, even in Mori's account of the breaking point (uncanny valley) some people might experience when the robotic or mechanical creatures they feel affinity towards appear too human-like.

Using clone characters in fiction is an effective instrument in posthuman narratives, because a clone "questions and destabilizes the boundaries between self and other, original and copy" and "opens up the question of technology's potential to alter human subjectivity" (Stout 2018, 97). Such issues as identity, nature vs. nurture, and determinism acquire new potential for application in plots, narration, psychological characterization, and in movie and television acting and representation. The clone characters in Orphan Black, for example, are performed by a single actress, Tatiana Maslany, whose representation may rest on her individual physique and appearance, yet she responds to the challenge of playing significantly different personalities by al- 
tering her posture, movement, gesture, as well as overall appearance. The visual medium of a television series allows this - unlike the literary examples in which the subjectivity of the cloned individuals is presented through narration (Kathy in Never Let $\mathrm{Me} \mathrm{Go}$ ) or by the behavior and psychological insight into the clones' collective psyche in Where Late the Sweet Birds Sang.

The uneasiness, strangeness, uncanniness, and otherness of the clones is what drives the plots, piques the interest of the reader or viewer, and generally offers sufficient material to discuss very conventional human themes in posthuman environments. As Amit Marcus proposes:

Clones are a particular type of other, being not simply similar to their originals but also their genetic copies, who nonetheless differ from their originals in their age, education, and the circumstances of their lives. All ethical issues discussed in bioethics concerning clones originate in the ambiguity between sameness and alterity, which is amplified in literary representations $(2012,430)$.

Clones are copies, but they are not necessarily the same. As Pence explains in a comprehensive passage about the factors influencing the genetic information in identical clones, if several clones are created from one original, their DNA would not be 100 percent the same (2016, 133-36). Another important factor - visible, for example, in Orphan Black - is how the varied environments (the wombs of different surrogate mothers, diverse upbringings, and experiences) contribute to their physical, mental, and emotional development, resulting in different personalities. In contrast, the clones in Where Late the Sweet Birds Sang and Never Let Me Go are brought up rather uniformly.

The fictional representation of clones, despite the indisputable variety of approaches taken by different individual authors, places them in environments in which they interact with two types of people: understanding, tolerating, even empathetic men and women who treat the clones with respect and humanity on the one hand (Miss Lucy in Ishiguro's novel, Donnie or Paul in Orphan Black); and power-driven and controlling individuals or institutions who objectify the clones and see them as a means to an end, commodities, instruments, and even political weapons on the other. Clones are either considered to be subhuman, being "less than human creatures [...] less 'authentic"' (Micali 2019, 34), or there is a prevalent fear that, in contrast, they "would be not subhuman but superhuman" (Pence 2016, 17). These attitudes, among other things, will be addressed in the analysis of the three selected works below.

\section{SAVIORS, NAIIFS, AND ORPHANS}

It is worthwhile firstly demonstrating that there is a certain chronological development in the portrayal of clone characters. The three selected works cover a time period of over forty years (1976-2017) and use different settings: Wilhelm's Where Late the Sweet Birds Sang is set in a post-apocalyptic situation where cloning is needed to preserve the human species; Ishiguro's Never Let Me Go (published in 2005) goes back to the 1990s to an alternative society where cloning is a real possibility used to produce cloned humans for organ donations; and Orphan Black is set in the early 21 st century with the main clone characters, all in their thirties, left searching for their identity and place in society. 
In terms of genre, while Wilhelm's novel is undeniably science fiction (a fact underscored by it being awarded the Hugo Award), Ishiguro's book balances between several genres (dystopia, Bildungsroman, and science fiction). Some scholars offer interesting analyses of the novel as a "speculative memoir" (McDonald 2007), while others provide a wide-ranging and thought-provoking discussion about the multiple genre categories of Never Let Me Go (Shaddox 2013, 449). The television series Orphan Black is primarily a thriller, with scientific, psychological, and sociological issues at its heart. It not only offers a very extensive and profound insight into the science of cloning, but also provides hints at its potential social and political impact.

The realistic and contemporary setting of Orphan Black contrasts with the post-apocalyptic backdrop of Where Late the Sweet Birds Sang; in the latter, the situation provides a good justification for human cloning: humans are infertile and would not survive as a species. In addition, the human community in which the story commences has already successfully cloned livestock to provide food for its members. The book thus becomes part of an important discussion about whether it is an "important moral duty" to preserve the human genome (Harris 2013, 134). As an example of a "clone narrative", Wilhelm's book represents a conventional science-fiction story (Marcus 2012, 406) which, nonetheless, extends its appeal beyond the traditional science-fiction readership. As Miroslav Kotásek argues: "[t]he social world is constructed by borrowing and utilizing components identifiable especially on the level of plot and story, used in science fiction to model and suggest new types of sociability up until now not fully realized" $(2015,68)$. In Where Late the Sweet Birds Sang, the interaction between humans and clones is depicted through the prism of diversity vs. individuality: there are clone groups made from male or female originals and collectively referred to as "brothers" or "sisters". The clones lack imagination and distinctiveness, and they suffer when they are separated from their siblings. In the course of the novel, the argument is made that cloning is not beneficial for a higher species like humans, because "it stifles diversity"; however, an objection is made that when a constant future of the (cloned) human race is concerned, diversity may not be always favorable: "You pay a high price for individuality" (Wilhelm 1998, 66).

For the clone community, who consider themselves to be the saviors of humankind, once the original humans are completely extinct it becomes imperative "to safeguard the well-being of the unit, not the various individuals within it. If there is a conflict between those two choices, we must abandon the individual. This is a given" (124). In a twist of Darwinian logic, this attitude - taught by the human originators of the clone community and learned by the clones because of their overly rational, unemotional, and unimaginative makeup - eventually produces "two castes [-] the leaders, and the workers, who were always expendable" (232). In other words, the clones learn everything their elders (makers) teach them, but that is where their creativity ends: "They could duplicate what had gone before, but they originated nothing" (193). Mark, a man who is reproduced sexually by two clones and the first of his kind to be allowed to live in their community, becomes an outcast and troublemaker who finds unity with nature and ultimately escapes the clones to establish his own community, which eventually becomes able to reproduce naturally. The perfec- 
tion associated with clones brings along a false sense of happiness: "[the clones] were happy because they didn't have enough imagination to look ahead [...] and anyone who tried to tell them there were dangers was by definition an enemy of the community. In disrupting their perfect existence, [Mark] had become an enemy" (238). Kate Wilhelm's posthuman environment thus allows her to highlight the contrast between the individuality and imagination of the humans (and only very few clones) and the uniformity and collective consciousness of the clones.

In Never Let Me Go, Kazuo Ishiguro, on the other hand, presents clones who are created in order to be used as organ donors (a premise similar to the 2005 film The Island, directed by Michael Bay). However, as opposed to The Island, where the characters decide to flee and fight their fate, the characters in Ishiguro's microcosm react to their identity (i.e., realizing they are clones) by peacefully accepting it (Schillings $2016,139)$. The only active and engaged form of revolt on their part is their decent demand to get "a deferral": a postponement, perhaps indefinite, of their having to start donating their organs. Their passivity, of course, is the result of their education at Hailsham - an institution that seems like a typical boarding school with a primary focus on the arts and humanities, as if such an approach would make the "unnaturally" made students more human. The important thing here is that Ishiguro's narrative makes the clone characters very human in terms of both its content and form.

The clones in Ishiguro's novel are humanized by being shown as creators and recipients of art, as well as by their struggle to deal with the loss of their "families": "For the parentless clones $[. .$.$] the demise of connective ties with familial others cre-$ ated in their years at Hailsham is more than losing friends and lovers; it is the loss of the medium through which they interconstitutively construct themselves as individuals" (Shaddox 2013, 459). Also, the form of narration makes use of a very intimate story told by one of the clones, Kathy, who uses second-person narration, "a device commonly used in Victorian fiction to enhance sympathetic connection" (Whitehead 2011, 58), which Karl Shaddox suggests is not dissimilar from the sentimental novel or abolitionist literature because it helps establish a connection between the protagonist and the reader $(2013,459)$. The novel portrays the clone characters, particularly towards the end, "as loving and sensitive individuals, even if they are not accorded the status and rights of citizens within the dystopian political system that has brought them into being" (Whitehead 2011, 56).

The clones are "naifs" who believe in the non-existing deferral, who experience humiliation, like, for example, Tommy (Ishiguro 2005, 7); they are repeatedly referred to by the "normals" as "shadowy objects in test tubes" (256) and creatures everyone is afraid of "as one might be afraid of spiders" (35). Miss Emily, the head of Hailsham, expresses the general fear and aversion to the clones as follows: "We are all afraid of you. I myself had to fight back my dread of you all almost every day I was at Hailsham" (264). This only further amplifies the "sympathetic connection" the reader feels with the clone characters and becomes a rudimentary form of what Rosi Braidotti calls "new affective assemblages" $(2017,21)$.

If the clones in Where Late the Sweet Birds Sang are saviors, and the clones in Never Let Me Go are naifs, then the female characters in Orphan Black, the Leda clones, 
are orphans: they grow up unaware of their status as clones with people who are not their biological parents. What is more, even their surrogate mothers remain mostly unknown. In the course of the series, however, their status as orphans is replaced by a kind of sisterhood: a unit (not dissimilar from the collective sense of togetherness in Kate Wilhelm's novel) that becomes important in the clones' struggle against their makers and would-be owners. The clones' authentic and autonomous personhood, as discussed by Gregory E. Pence and cited above, is shown in the way the clones use their individual identity and self-awareness while constantly combatting attempts to subjugate them. John C. Stout presents a comprehensive analysis of how the importance of family, orphanhood, and identity for the clones in Orphan Black (2018, 98) extends the view that the series expresses "our current fears, anxieties and desires surrounding the discovery of genes as the ultimate truth of who we are" (Goulet and Rushing 2018, 18).

In a similar vein, Orphan Black focuses on the importance of control and surveillance in the posthuman condition - the clones are being monitored by various corporate institutions whose objectives range from medical research, through transhumanist enhancement, all the way to a quest for the fountain of youth. In addition, as Andrea Goulet and Robert A. Rushing posit, "control over women's bodies, health and reproduction is absolutely central to Orphan Black" $(2018,7)$; the show is also "a critique of the constant scrutiny - social, legal, medical - given to women's bodies" (11). As opposed to the clones in Where Late the Sweet Birds Sang, and partly also in Never Let $\mathrm{Me} \mathrm{Go}$, the story of Orphan Black ends up cherishing diversity and individuality.

\section{"MANY HAPPY AND EXCELLENT NATURES"}

A straightforward conclusion may be drawn about the three selected works: they represent an advancement in the portrayal of clone characters in fiction - from the functional instruments of human reproduction in a post-apocalyptic scenario to complex psychological and social depictions in modern-day narratives which balance on the edge of realism and science fiction. Simultaneously, the novels and TV series progressively employ their readers' and viewers' ability to imagine posthuman social setups and juxtaposing them to the contemporary condition. Or, as Mads Rosendahl Thomsen has suggested: "There is an uncanny feeling to imagining a more advanced culture, or a being more advanced than the human, which would put existing humanity into a broader perspective as just one element in a long evolution" $(2015,55)$. The three works discussed above try to play along with that uncanny feeling and imagine similar social conditions. Of course, such fictional accounts always recognize the "anxiety over the desire to pursue scientific knowledge and control nature as the ultimate goal of humanity," particularly the potentially "regrettable motives and disastrous results" of such efforts (Marcus 2012, 407).

Analyzing posthuman fiction and cinema, for example through the prism of the authors' approach to characterization and narration, offers a chance to address important questions of tomorrow, including the potential of human social cooperation, the effects of corporate and political power, and the ethics of progressive medical research. Such a discussion necessarily extends to the relevance of "man- 
ufactured and patented bio-products [and] the ethical imperative to bind to them and be accountable for their well-being," while simultaneously recognizing the need for "new genealogies, alternative theoretical and legal representations of the new kinship systems and adequate narratives" (Braidotti 2013, 80). Also, as Peter Sýkora suggests, now that "the genetic enhancements of both humans and animals, including their cognitive capacity, has become reality, the discussion about them is no longer a thought experiment, but a challenge for mankind that will have to be dealt with as soon as possible - ethically, philosophically, politically, and legally" $(2019,524$, trans. I.L.).

Our ability to challenge well-established social, cultural, and political systems, and oversee their constant analysis and adaptation, will prove instrumental as the posthuman condition becomes more complex. The existing social polarization in several areas, based on a dualist approach to social and cultural interaction, might lead to enhanced modes of labelling, control, and discrimination. Or, as Francesca Ferrando aptly puts it: "Even if post-humanistic and post-anthropocentric social performances may eventually overcome some forms of discrimination, such as racism, sexism, and speciesism, if we do not embrace post-dualism and critically address, and deconstruct, rigid forms of dualistic identity-formation practices, other forms of discrimination will consistently continue to arise" $(2019,189)$. If humans are able to align their scientific determination with the pace of socio-cultural development, our posthuman future might get to see Viktor Frankenstein's dream of "many happy and excellent natures" owing their existence and life to us.

\section{LITERATURE}

Bakošová, Pavlína, and Juraj Odorčák. 2020. "Posthumanism and Human Extinction: Apocalypse, Species, and Two Posthuman Ecologies." Journal for the Study of Religions and Ideologies 19, 57: 47-62.

Baudrillard, Jean. 1994. Simulacra and Simulation. Trans. by Sheila Faria Glaser. Ann Arbor, MI: University of Michigan Press.

Braidotti, Rosi. 2013. The Posthuman. Cambridge: Polity.

Braidotti, Rosi. 2017. "Posthuman Critical Theory." Journal of Posthuman Studies 1, 1: 9-25. DOI: https://doi.org/10.5325/jpoststud.1.1.0009.

Clarke, Bruce, and Manuela Rossini. 2017. "Preface: Literature, Posthumanism, and the Posthuman." In The Cambridge Companion to Literature and the Posthuman, ed. by Bruce Clarke and Manuela Rossini, xi-xxii. New York, NY: Cambridge University Press. DOI: https://doi. org/10.1017/9781316091227.

Clarke, Bruce, and Manuela Rossini, eds. 2017. The Cambridge Companion to Literature and the Posthuman. New York, NY: Cambridge University Press. DOI: https://doi. org/10.1017/9781316091227.

Collebrook, Claire. 2017. "Futures." In The Cambridge Companion to Literature and the Posthuman, ed. by Bruce Clarke and Manuela Rossini, 196-208. New York, NY: Cambridge University Press. DOI: https://doi.org/10.1017/9781316091227.

Ferrando, Francesca. 2014. “The Body." In Post- and Transhumanism: An Introduction, ed. by Robert Ranisch and Stefan L. Sorgner, 213-226. New York, NY: Peter Lang. DOI: https://doi.org/10.3726/9783-653-05076-9.

Ferrando, Francesca. 2019. Philosophical Posthumanism. London: Bloomsbury Academic. 
Franklin, Sarah. 2006. "Better by Design?” In Better Humans? The Politics of Human Enhancement and Life Extension, ed. by Paul Miller and James Wilsdon, 86-94. London: Demos.

Freud, Sigmund. 1919. “Das Unheimliche (The Uncanny)." In Standard Edition of the Complete Psychological Works, ed. and trans. by James Strachey, 217-252. London: The Hogarth Press.

Goulet, Andrea, and Robert A. Rushing, eds. 2018. Orphan Black: Performance, Gender, Biopolitics. Bristol: Intellect.

Halberstam, Judith, and Ira Livingston, eds. 1995. Posthuman Bodies. Bloomington, IN: Indiana University Press.

Harris, John. 2013. “Enhancements Are a Moral Obligation.” In Human Enhancement, reprint edition, ed. by Julian Savulescu and Nick Bostrom, 131-154. Oxford: Oxford University Press.

Hayles, N. Katherine. 1999. How We Became Posthuman: Virtual Bodies in Cybernetics, Literature, and Informatics. Chicago, IL and London: University of Chicago Press.

Ishiguro, Kazuo. 2005. Never Let Me Go. London: Faber and Faber.

Karkulehto, Sanna, Aino-Kaisa Koistinen, and Essi Varis. 2019. Reconfiguring Human, Nonhuman and Posthuman in Literature and Culture. New York, NY: Routledge. DOI: https://doi. org/10.4324/9780429243042.

Kotásek, Miroslav. 2015. "Artificial Intelligence in Science Fiction as a Model of the Posthuman Situation of Mankind." World Literature Studies 7, 4: 64-77.

Marcus, Amit. 2012. "The Ethics of Human Cloning in Narrative Fiction." Comparative Literature Studies 49, 3: 405-433.

McDonald, Keith. 2007. 'Days of Past Futures: Kazuo Ishiguro's 'Never Let Me Go' as a 'Speculative Memoir"' Biography 30, 1: 74-83.

Miah, Andy. 2008. "A Critical History of Posthumanism." In Medical Enhancement and Posthumanity, ed. by Bert Gordijn and Ruth Chadwick, 71-94. Dordrecht: Springer.

Micali, Simona. 2019. Towards a Posthuman Imagination in Literature and Media: Monsters, Mutants, Aliens, Artificial Beings. Oxford: Peter Lang. DOI: https://doi.org/10.3726/b14448.

More, Max, and Natasha Vita-More, eds. 2013. The Transhumanist Reader: Classical and Contemporary Essays on the Science, Technology and Philosophy of the Human Future. Malden, MA: Wiley-Blackwell. DOI: https://doi.org/10.1002/9781118555927.

Mori, Masahiro. 2012. "The Uncanny Valley." Trans. by Karl F. MacDorman and Norri Kageki. IEEE Robotics \& Automation Magazine 19, 2: 98-100. DOI: https://doi.org/10.1109/MRA.2012.2192811.

Pence, Gregory E. 2016. What We Talk About When We Talk About Clone Club: Bioethics and Philosophy in Orphan Black. Dallas, TX: Smart Pop.

Peterson, Christopher. 2011. "The Posthumanism to Come." Angelaki 16, 2: 127-141. DOI: https://doi. org/10.1080/0969725X.2011.591592

Rosendahl Thomsen, Mads. 2015. The New Human in Literature: Posthuman Visions of Changes in Body, Mind and Society after 1900. London and New York, NY: Bloomsbury Academic.

Rossini, Manuela. 2005. "Figurations of Posthumanity in Contemporary Science/Fiction: All Too Human(ist)?" Revista Canaria de Estudios Ingleses 50, April: 21-36.

Sandel, Michael J. 2013. “The Case Against Perfection: What's Wrong with Designer Children, Bionic Athletes, and Genetic Engineering." In Human Enhancement, reprint edition, ed. by Julian Savulescu and Nick Bostrom, 71-90. Oxford: Oxford University Press.

Shaddox, Karl. 2013. "Generic Considerations in Ishiguro's 'Never Let Me Go"' Human Rights Quarterly 35, 2: 448-469. DOI: https://doi.org/10.1353/HRQ.2013.0026.

Shelley, Mary Wollstonecraft. 2012. Frankenstein. London: Penguin.

Schillings, Sonja. 2016. "The Dignity of Dead Tissue: Education, Oppression, and Family in Kazuo Ishiguro's 'Never Let Me Go.' In Family and Kinship in the United States: Cultural Perspectives on Familial Belonging, ed. by Karolina Golimowska, Reinhard Isensee, and David Rose, 139-158. Frankfurt am Main and New York, NY: Peter Lang. DOI: https://doi.org/10.3726/978-3-653-04773-8.

Stout, John C. 2018. “Game of Clones: Orphan Black’s Family Romance." In Orphan Black: Performance, Gender, Biopolitics, ed. by Andrea Goulet and Robert A. Rushing, 96-111. Bristol: Intellect.

Sýkora, Peter. 2019. "K posthumánnemu človeku prostredníctvom editovania génov pre kognitívne schopnosti." Filozofia 74, 7: 511-529. DOI: https://doi.org/10.31577/filozofia.2019.74.7.1. 
Vita-More, Natasha. 2013. "Aesthetics: Bringing the Arts \& Design into the Discussion of Transhumanism." In The Transhumanist Reader: Classical and Contemporary Essays on the Science, Technology and Philosophy of the Human Future, ed. by Max More and Natasha Vita-More, 18-27. Malden, MA: Wiley-Blackwell. DOI: https://doi.org/10.1002/9781118555927.

Wells, H. G. 2005. The Island of Doctor Moreau. London: Penguin.

Whitehead, Anne. 2011. "Writing with Care: Kazuo Ishiguro's 'Never Let Me Go." Contemporary Literature 52, 1: 54-83.

Wilhelm, Kate. 1998. Where Late the Sweet Birds Sang. New York, NY: Orb Books.

\title{
CITED AUDIOVISUAL WORK
}

Orphan Black (directed by John Fawcett and Graeme Manson, Canada, 2013-2017)

The Island (directed by Michael Bay, United States of America, 2005)

\section{Saviors, naïfs, or orphans? The posthuman condition in literary and cinematic perspectives on human cloning}

Posthuman. Posthumanism. Cloning. Clone narratives. Genetic determinism. Nature vs. nurture. Human genome editing.

This article focuses on cloning as a relevant trans- and posthumanist theme presented in the classical science fiction of the 1970s (Kate Wilhelm's Where Late the Sweet Birds Sang), 21st-century literary fiction (Kazuo Ishiguro's Never Let Me Go), and streaming television series made in the 2010s (BBC America's Orphan Black). With special emphasis on the subject of human cloning, the article will endeavor to discuss questions of identity in a posthuman environment, tracing the development from Wilhelm's dystopian and post-apocalyptic scenarios in which clones and humans interact to disastrous ends, through Ishiguro's psychological and emotional exploration of the inner world of cloned individuals whose fates are narrated in a form similar to the Bildungsroman, all the way to the complex study of nature vs. nurture in the cloned characters of Orphan Black.

\author{
Mgr. Ivan Lacko, PhD. \\ Department of British and American Studies \\ Faculty of Arts \\ Comenius University \\ Gondova 2 \\ 81499 Bratislava \\ Slovak Republic \\ ivan.lacko@uniba.sk \\ ORCID ID: https://orcid.org/0000-0003-3494-3990
}

